Original Research

\title{
Possible Influence of Agriculture on an Unsaturated Zone in Croatia
}

\author{
Stanko Ružičić1*, Zoran Kovač², Tin Borovčak ${ }^{1}$ \\ ${ }^{1}$ Department of Mineralogy, Petrology and Mineral Resources, Faculty of Mining, Geology \\ and Petroleum Engineering, University of Zagreb, Zagreb, Croatia \\ ${ }^{2}$ Department of Geology and Geological Engineering, Faculty of Mining, Geology and Petroleum Engineering, \\ University of Zagreb, Zagreb, Croatia
}

Received: 30 April 2018

Accepted: 30 October 2018

\begin{abstract}
Soil contamination in the agricultural areas developed on open aquifer systems can be environmental problem. The subject of this study is the Cambisol soil developed in the area of the Velika Gorica well field. The aim of this research was to determine possible agricultural influence on the unsaturated zone of the Zagreb aquifer area where Cambisol soil is developed. Concentrations of potentially toxic metals $(\mathrm{Cu}, \mathrm{Cd}$ and $\mathrm{Zn})$ and major cations and anions $\left(\mathrm{Na}^{+}, \mathrm{K}^{+}, \mathrm{NH}_{4}^{+}, \mathrm{Mg}^{2+}, \mathrm{Ca}^{2+}, \mathrm{Cl}^{-}, \mathrm{NO}_{3}^{-}\right.$, and $\left.\mathrm{SO}_{4}^{2-}\right)$ were determined in soil horizons. Correlations between physical and chemical soil properties, analysed ions and potentially toxic metals were made. Samples that were closer to the surface showed increased element concentrations, indicating the increased impact of agricultural activities in the research area. All analysed potentially toxic metals showed highest concentrations in residual fraction, which indicates the possible influence of agricultural activities such as usage of fertilizers, manure, sludge as soil fertilizer and fungicides, or point sources of contamination, uncontrolled, active or untended waste dumps and aerodeposition. Statistical analysis showed strong correlations between the concentrations of the studied potentially toxic metals and some soil properties such as soil texture, $\mathrm{pH}$ and organic matter. In addition, correlation results between nitrates and some potentially toxic metals such as $\mathrm{Cu}$ and $\mathrm{Zn}$ indicate that these elements come from the same source of contamination, in this case probably agricultural activity. Even though the influence of agricultural activities is recognized, all results show that the impact is decreasing after approximately $0.8 \mathrm{~m}$ depth.
\end{abstract}

Keywords: agricultural activities, unsaturated zone, potentially toxic metals, cations and anions, Cambisol

*e-mail: stanko.ruzicic@rgn.hr 


\section{Introduction}

Increased concentrations of anions and cations, as well as potentially toxic metals in the agricultural soils developed in the area of water field Velika Gorica, can present environmental risk. One of the sources for contamination by potentially toxic metals are agricultural inputs. Agricultural inputs can be from animal manure and artificial fertilizers, which are enriched with potentially toxic metals. Triple super phosphates and calcium/magnesium phosphate contain varying concentrations of cadmium [1], while copper and zinc are substantially added to soils by agricultural practices [2]. Both elements are used widely as fertilizers and stimulants of animal growth [3]. Considering agricultural soils, the accumulation of potentially toxic metals may have different effects, either directly endangering the natural soil functions, or indirectly endangering the biosphere by bioaccumulation and inclusion in the food chain. Many previous studies were made to get information about soil accumulation of potentially toxic metals from agriculture. Medunić et al. [4] studied the fractionation of copper and zinc in apple orchard soil using sequential extraction procedure. They concluded that copper and zinc are bounded to residual and reducible fractions and their total values do not exceed maximal permissible concentrations (MAC) in agricultural land.

Apart from potentially toxic metals, a load of cations and anions from agricultural sources can also present risks for groundwater pollution. Agriculture presents one of the most prevalent diffuse nitrogen sources. Inorganic nitrogen fertilizers are applied to increase the immediate availability of nitrogen for plant growth [1]. Bubalo et al. [5] studied agricultural impact on groundwater vulnerability using nitrates. The authors concluded that the study area is highly vulnerable to nitrate, especially those from agricultural origin. Potassium is an essential and major nutrient for crop production [6]. Manure has potassium in its compounds, and an excessive load of this product to agricultural soil may result in very high concentrations of this element in soils and groundwater.

Therefore, the goal of this research was to determine the main soil properties and soil accumulation of potentially toxic metals and cations/anions under long cultivation in Cambisol located in the vicinity of the Velika Gorica well field.

\section{Material and Methods}

\section{Study Site Description}

The study area is in the immediate vicinity of the well field Velika Gorica, which is located in the SE part of the Zagreb aquifer (Fig. 1). The well field Velika Gorica is situated in the western part of the city of Velika Gorica.

Variable lithology, pedological characteristics and land use characterize the study site. The study area consists of a large alluvial plain that has two marked

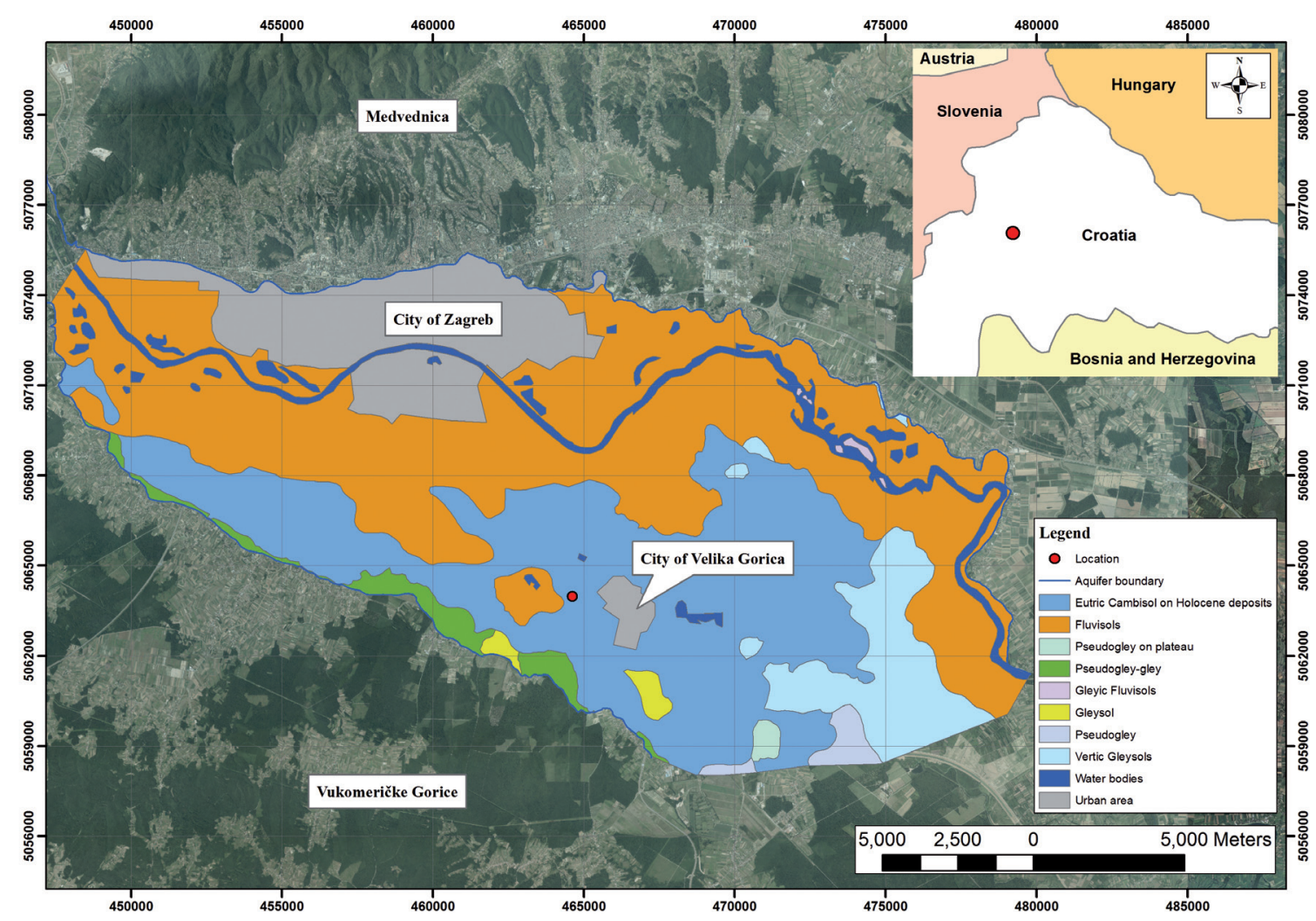

Fig. 1. Pedological map of Zagreb aquifer system with location of soil profile. 
geomorphological features: the raised sealed terrace of the Sava River (varying in width down the river's length), and a Holocene terrace [7]. Numerous meanders of the Sava River inundated fluvial cones, and numerous bowl-shaped depressions abound in the alluvial plain. The climate of the Velika Gorica is classified as a moderately continental climate (Cfwbx in the Köppen climate classification system) with four separate seasons. Summers are warm, and winters are cold, without a discernible dry season.

The study area consists mainly of Quaternary deposits made of Pleistocen non-carbonate loess, Holocene alluvium of the first terrace of the Sava River, flooding sediments and alluvium splay sediments [8]. There are two different water-bearing layers: first waterbearing layer with the dominantly alluvial sediments of the Sava River and second water-bearing layer with predominantly lake-pond deposits. The first layer contains Holocene alluvial deposits [9], which are in direct contact with the Sava River, which is very pronounced in the vicinity of the Sava [10]. According to Velić and Durn [9], the second water-bearing layer contains Pleistocene lacustrine-marshy deposits. Even though they present one hydrogeological unit, geochemical stratification along the depth is recognized [11]. The thickness of the unsaturated zone in the Zagreb area generally varies from $8 \mathrm{~m}$ in the NW part to $2 \mathrm{~m}$ in the SE part [12].

The study area is generally made form three main pedological units, Fluvisols, Pseudogley on plateau and Eutric Cambisols developed on the Holocen deposits [13]. The investigated pedological profile is situated in Eutric Cambisols on the Holocen deposits. The following soil horizons were recognized: A-Bw-C-2C$3 \mathrm{C}$. The texture of these soils is silty clay loam. Soil structure is mainly granular. The presence of the clayey cambic horizon with the structure of pedological profile A- (B) W-C is characteristic for the specified soil. The upper part of this soil profile is generally permeable, which enables the infiltration of water and potential contaminants into the aquifer [14]. In the area of Zagreb aquifer Cambisols were developed at fluvial loamy deposits where groundwater reaches the $1 \mathrm{~m}$ depth [13].

\section{Field and Laboratory Work}

Field research was conducted in the area of the Velika Gorica well field, which is located west of Velika Gorica. The field research consisted of borehole drilling, sampling, a description of the pedological profile and recognition of the soil horizons (A-Bw-C-2C-3C).

Five disturbed soil samples for laboratory analysis were collected from soil horizons. Soil samples were air-dried and passed through a $2 \mathrm{~mm}$ sieve for laboratory analysis. Particle size distribution was determined by sieving and pipette methods. Mineral composition of $<2 \mathrm{~mm}$ and $<2 \mu \mathrm{m}$ fractions of the analysed soils was determined by X-ray powder diffraction (XRD) using a Philips diffractometer (graphite monochromator, $\mathrm{CuK} \alpha$ radiation, proportional counter). The identification of clay minerals was generally based on the methods outlined by Moore and Reynolds [15]. Carbonate content was determined by the volumetric method [16], iron and manganese extractable with $\mathrm{Na}$ dithionite-citrate bicarbonate were obtained by the method of Mehra and Jackson [17], while organic matter was determined using a hydrogen peroxide solution. Cation exchange capacity (CEC) was determined using barium chloride solution [18]. Determination of anions and cations on the previously frozen soil samples was performed using the method of ion chromatography (ICS-90).

Ion chromatography is a part of liquid chromatographic techniques with which the ions can be separated and detected. This method was used to determine the concentrations of sodium $\left(\mathrm{Na}^{+}\right)$, potassium $\left(\mathrm{K}^{+}\right)$, ammonium $\left(\mathrm{NH}_{4}^{+}\right)$, magnesium $\left(\mathrm{Mg}^{2+}\right)$, calcium $\left(\mathrm{Ca}^{2+}\right)$, chlorides $\left(\mathrm{Cl}^{-}\right)$, nitrates $\left(\mathrm{NO}_{3}^{-}\right)$and sulphates $\left(\mathrm{SO}_{4}^{2-}\right)$ in each soil horizon. The steps of sample preparation for ions determination are described in detail. Each soil sample $(10 \mathrm{~g})$ was put in $100 \mathrm{~mL}$ glass and diluted with ultra-pure water (conductivity less than $1 \mu \mathrm{S} / \mathrm{cm}$ ) to stay overnight. After that, samples were put on a shaker for 1 hour. Suspensions were then centrifuged at $3000 \mathrm{rpm}$ for $20 \mathrm{~min}$ and filtrated. Geochemical fractionation of potentially toxic metals in selected soils were analysed using sequential extraction. A series of reagents was used to extract operationally defined metal species (the selectivity depends on such

Table 1. Sequential extraction procedure applied in this study.

\begin{tabular}{|c|c|c|c|c|}
\hline Step & Fraction & Label & Reagent/concentration/volume & Conditions \\
\hline 1. & Acid & CARB & Acetic acid $\left(\mathrm{CH}_{3} \mathrm{COOH}\right) / 0.11 \mathrm{~mol} / 1 / 40 \mathrm{ml}$ & $\mathrm{pH} 2.9,16 \mathrm{~h}$ agitation at $20^{\circ} \mathrm{C}$ \\
\hline 2. & Reducible & FEMN & $\begin{array}{l}\text { Hydroxylamine hydrochloride }\left(\mathrm{NH}_{2} \mathrm{OHxHCl}\right) / \\
0.5 \mathrm{~mol} / \mathrm{l} / 40 \mathrm{ml}\end{array}$ & $\begin{array}{c}\mathrm{pH} 2 \text { (regulated with } \mathrm{HNO}_{3} \text { ), } \\
16 \text { h agitation at } 20^{\circ} \mathrm{C}\end{array}$ \\
\hline 3. & Oxidisable & $\mathrm{OM}$ & $\begin{array}{l}\text { Hydrogen peroxide }\left(\mathrm{H}_{2} \mathrm{O}_{2}\right) / 8.8 \mathrm{~mol} / \mathrm{l} / 10 \mathrm{ml}+10 \mathrm{ml} \\
\text { Ammonium acetate }\left(\mathrm{NH}_{4} \mathrm{OOCCH}_{3}\right), 1 \mathrm{~mol} / \mathrm{l} / 50 \mathrm{ml}\end{array}$ & $\begin{array}{c}1 \mathrm{~h} \text { at } 20^{\circ} \mathrm{C}, \text { occasional shaking, } \\
2 \mathrm{~h} \text { water bath at } 85^{\circ} \mathrm{C} \\
\left.\mathrm{pH} 2 \text { (regulated with } \mathrm{HNO}_{3}\right) \\
16 \text { h agitation at } 20^{\circ} \mathrm{C}\end{array}$ \\
\hline 4. & Total & RES & $\begin{array}{c}\text { Hydrochloric acid }(\mathrm{HCl}) / 37 \% / 7 \mathrm{ml} \\
\text { Nitrit acid }\left(\mathrm{HNO}_{3}\right) / 65 \% / 2.3 \mathrm{ml}\end{array}$ & $\begin{array}{c}2 \mathrm{~h} \text { water bath at } 100^{\circ} \mathrm{C} \text {, cooling at room } \\
\text { temperature }\end{array}$ \\
\hline
\end{tabular}


Table 2. Physical and chemical characteristics of studied soil profile.

\begin{tabular}{|c|c|c|c|c|c|c|c|c|c|}
\hline $\begin{array}{c}\text { Soil } \\
\text { horizons }\end{array}$ & $\begin{array}{c}\text { Soil } \\
\text { Depth (m) }\end{array}$ & Colour & $\mathrm{pH}(\mathrm{KCl})$ & $\begin{array}{c}\text { Sand } \\
(\%)\end{array}$ & $\begin{array}{c}\text { Silt } \\
(\%)\end{array}$ & $\begin{array}{c}\text { Clay } \\
(\%)\end{array}$ & $\begin{array}{c}\text { OM } \\
(\%)\end{array}$ & $\begin{array}{c}\text { Carbonate } \\
(\mathrm{mass} \%)\end{array}$ & $\begin{array}{c}\text { CEC } \\
(\mathrm{meq} / 100)\end{array}$ \\
\hline $\mathrm{A}$ & $0-0.2$ & $5 \mathrm{Y} / 4 / 2$ & 6.36 & 16 & 60 & 24 & 8.98 & 16.77 & 34.43 \\
\hline $\mathrm{Bw}$ & $0.2-0.4$ & $5 \mathrm{Y} / 4 / 2$ & 6.57 & 5 & 58 & 37 & 10.18 & 15.90 & 31.74 \\
\hline $\mathrm{C}$ & $0.4-0.6$ & $5 \mathrm{Y} / 4 / 3$ & 7.05 & 5 & 55 & 40 & 9.19 & 22.94 & 37.48 \\
\hline 2C & $0.6-0.8$ & $5 \mathrm{Y} / 4 / 3$ & 6.93 & 7 & 54 & 39 & 7.97 & 21.25 & 24.63 \\
\hline $3 \mathrm{C}$ & $0.8-1.1$ & $5 \mathrm{Y} / 3 / 2$ & 6.47 & 9 & 50 & 41 & 7.16 & 6.73 & 19.55 \\
\hline
\end{tabular}

factors as chemicals employed, the time and nature of contact, and the sample-to-volume ratio) in a defined sequence from $1 \mathrm{~g}$ of the sample. Sequential extraction scheme (Table 1) was used according to Rauret et al. [19] and it gave four fractions: acid (bound to carbonates-CARB), reducible (bound to iron and manganese oxides, hydroxides and oxyhydroxidesFEMN), oxidizable (bound to organic matter and/or sulphides-OR/SUL) and residual (total dissolving using aquaregia-RES). Sequential extraction was conducted in centrifuge tubes (polyethylene, $50 \mathrm{ml}$ ). Between each successive extraction step, the liquid phase was separated by centrifuge at $3000 \mathrm{rpm}$ for 10 minutes. All the reagents used in the extraction procedures were of analytical grade. The resulting solutions were analysed by flame atomic absorption spectrometry (AAnalyst 700, Perkin Elmer). The correlation between analysed soil properties and elements was estimated by Pearson correlation coefficient. This statistical analysis was done using Statistica 64 [20].

\section{Results and Discussion}

Table 2 presents physical and chemical characteristics of studied soil profile. The texture of analysed soil is silty clay loam. The highest proportion of sand is determined in A horizon and the smallest in $\mathrm{C}$ horizon, which is in correlation with the highest CEC value for this depth. The smallest CEC value is determined in $3 \mathrm{C}$ horizon, which is not in correlation with the proportion of clay, but it correlates with OM. Values of $\mathrm{pH}$ are varied from 6.36 to 7.05 , which represent uniformity by changing the depth. Deviation of $\mathrm{pH}$ values has a sample taken from $\mathrm{C}$ horizon showing neutral conditions. Change in $\mathrm{pH}$ values along the soil profile can be associated with a change of carbonates, while alkalinity of the soil with the presence of magnesium and calcium carbonates [21]. Similar chemical characteristics ( $\mathrm{pH}$ and CEC) of Cambisol were reported by Ružičić et al. [22].

The highest percentages of organic matter were determined in $\mathrm{A}, \mathrm{Bw}$ and $\mathrm{C}$ horizons, and with increasing depth these values gradually fall. Organic matter generally has very high CEC values. In this study, organic matter showed similar distribution characteristics with CEC values.
The sequential chemical analysis presented diverse distribution in sequenced fractions of investigated soil. The average proportion of $\mathrm{Cu}$ fraction in soil horizons was arranged in the following decreasing orders: RES $(72-81 \%)>$ OR/SUL $(19-26 \%)>$ FEMN $(0-2 \%)>$ CARB (0\%) (Fig. 2). A similar order in Cambisol type of soil was reported by Leśniewska et al. [23]; Nogueirol and Alleoni [24]; Ružičić et al. [25]; and Pakuła and Kalembasa [26]. The highest concentration (81\%) of $\mathrm{Cu}$ in the analysed soil was detected in the residual fraction in A horizon (Fig. 2). The highest copper concentration in the top soil horizon of our study soil profile can be from agricultural agents such as fungicides. In addition, most of the copper concentration accumulated in leaves and soil by spraying can be retained in topsoil through the biological cycle and tillage [27]. Although a higher concentration of copper in soils can be from agricultural practices, it can be from other sources. Romić and Romić [28] in this study area found higher concentrations of copper, which are a consequence of point sources of contamination, uncontrolled, active or untended waste dumps. The second highest enrichment of $\mathrm{Cu}$ is in OR/SUL or oxidizable fraction.

The average proportion of $\mathrm{Zn}$ fraction in soil horizons was distributed in the following decreasing orders: RES $(61-80 \%)>$ OR/SUL $(11-14 \%)>$ FEMN (5-9\%) > CARB (0-20\%) (Fig. 3). Medunić et al. [4]; Dabiri et al. [29]; Ružičić et al. [25]; Bakircioglu et al. [30]; and Liu et al. [31] found the same orders of $\mathrm{Zn}$ fractioning in Cambisol. In soil, zinc forms complexes with organic matter quite quickly, and this has a holding-

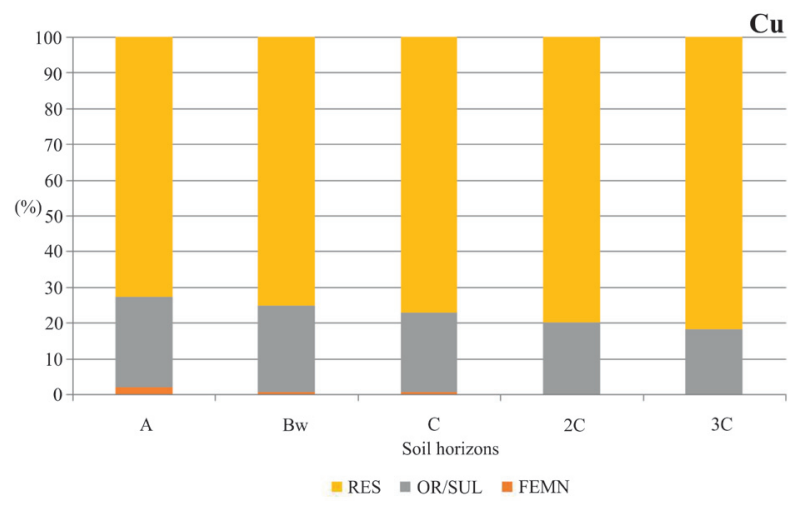

Fig. 2. Distribution of copper in fractions in soil profile. 


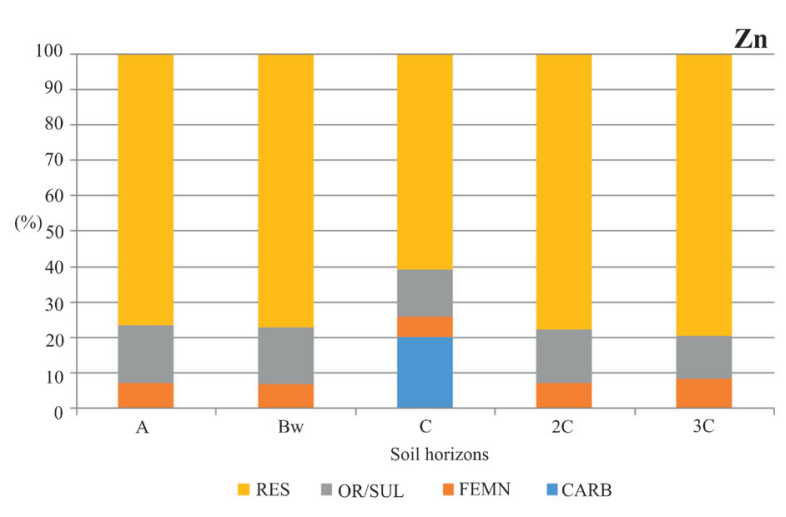

Fig. 3. Distribution of zinc in fractions in soil profile.

back effect on the activity of $\mathrm{Zn}$ in the soil solution [32]. Although copper shows generally much higher affinity to $\mathrm{OM}$ as compared to zinc, it is possible that zinc is also bound with organic matter, which can be seen in Table 4.

The average proportion of $\mathrm{Cd}$ fraction in soil horizons was distributed in the following decreasing orders: RES $(15-80 \%)>$ FEMN $(10-100 \%)>$ CARB $(0-15 \%)>$ OR/ SUL (0\%) (Fig. 4). The proportion of FEMN-extractable $\mathrm{Cd}$ in A horizon is $100 \%$. The percentage of FEMN fraction decreased with depth. Ahmadipour et al. [33] found that FEMN fraction makes approximately $90 \%$ of the $\mathrm{Cd}$ in subsurface soil. The amounts of organic and sulphide-bound cadmium (OR/SUL) are not detected in all soil horizons (Fig. 4). Cadmium is mostly bound to RES fraction, which can be related to anthropogenic sources such as the application of fertilizers.

Even goethite is present as a minor mineral phase according to mineralogical analysis, and it can be related to FEMN fraction in analysed soil. Zhang et al. (2013) [34] showed that $\mathrm{Cd}$ variations in arable soil are greatly influenced by parent material and soil properties, as well as human activities, such as industrial production, traffic and the application of fertilizers.

The highest concentrations of cations in studied soil were determined in $2 \mathrm{C}$ horizon, with the exception of ammonium (Fig. 5). The lowest concentrations of cations

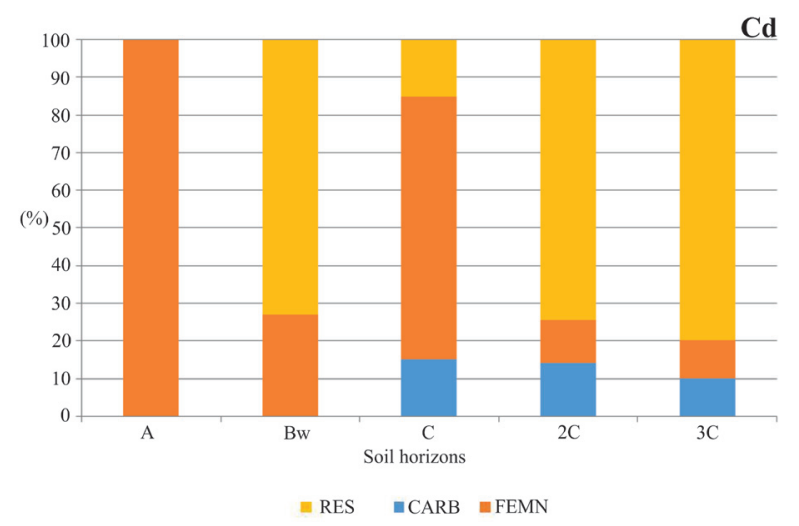

Fig. 4. Distribution of cadmium in fractions in soil profile.

were determined in A horizon, with the exception of sodium. The potassium concentration in analysed soil varied from $42 \mathrm{mg} / \mathrm{kg}$ to $119 \mathrm{mg} / \mathrm{kg}$ (Fig. 5). Mocanu et al. [35] reported similar concentrations of potassium in Cambisol. The calcium varied from $1164 \mathrm{mg} / \mathrm{kg}$ to $2326 \mathrm{mg} / \mathrm{kg}$ (Fig. 5). Sedlář et al. [36] determined approximately $1743 \mathrm{mg} / \mathrm{kg}$ of calcium concentrations in Cambisol. Magnesium varied from $428 \mathrm{mg} / \mathrm{kg}$ to 864 $\mathrm{mg} / \mathrm{kg}$ (Fig. 5). Ammonium content in analysed soil varied between $24 \mathrm{mg} / \mathrm{kg}$ to $55 \mathrm{mg} / \mathrm{kg}$ (Fig. 5). Bakšić et al. [37] got similar concentrations of ammonium in A horizon of Cambisol.

The highest concentrations of anions in studied soil were determined in $\mathrm{A}, \mathrm{C}$ and $2 \mathrm{C}$ horizons (Fig. 6). Sulphates varied from $57 \mathrm{mg} / \mathrm{kg}$ (3C horizon) to $90 \mathrm{mg} / \mathrm{kg}$ (C horizon). The highest chloride concentrations $(3027 \mathrm{mg} / \mathrm{kg})$ were determined in $2 \mathrm{C}$ horizon, which correspond to calcium concentrations. Nitrates varied from $59 \mathrm{mg} / \mathrm{kg}$ (C horizon) to $307 \mathrm{mg} / \mathrm{kg}$ (A horizon) (Fig. 6). The lowest chloride and nitrate concentrations were determined in $\mathrm{C}$ horizon. Nitrate concentration generally decreased from the surface to the end of investigated soil profile, which is probably controlled with soil texture and human activities in surface horizons (Fig. 6). Bubalo et al. [5] reported the same trend during their research of nitrate concentration through soil depth. These results

Table 3. Mineral content of soil samples; legend: +++ -dominant mineral phase; ++ - significantly present mineral phase; + - minor mineral phase; ? - mineral in the sample is not reliably determined (due to its small share and/or due to overlapping of its diffraction pattern with diffraction pattern of another minerals); MM- mixed clay minerals; Chl-Vrm- chlorite-vermiculite; Vrm- vermiculite.

\begin{tabular}{|c|c|c|c|c|c|c|c|c|c|}
\hline $\begin{array}{c}\text { Depth } \\
(\mathrm{m})\end{array}$ & Quartz & Plagioclase & Goethite & $\begin{array}{c}\text { Illitic } \\
\text { material }\end{array}$ & Kaolinite & Chlorite & $14 \AA$ mineral & MM & Dolomite \\
\hline $0-0.2$ & + & + & + & +++ & ++ & $++/+++$ & $\begin{array}{c}+/++ \\
(\text { Vrm? and/or Chl-Vrm?) }\end{array}$ & + \\
\hline $0.2-0.4$ & + & $?$ & + & +++ & ++ & $++/+++$ & $++($ Vrm $)$ & + & + \\
\hline $0.4-0.6$ & + & $?$ & + & +++ & ++ & $++/+++$ & $++($ Vrm $)$ & + & + \\
\hline $0.6-0.8$ & + & $?$ & + & $++/+++$ & ++ & $++/+++$ & $?$ & + & + \\
\hline $0.8-1.1$ & + & $?$ & + & +++ & ++ & $\begin{array}{c}++ \\
\text { (and Chl-Vrm?) }\end{array}$ & ++ & $+/++$ & + \\
\hline
\end{tabular}




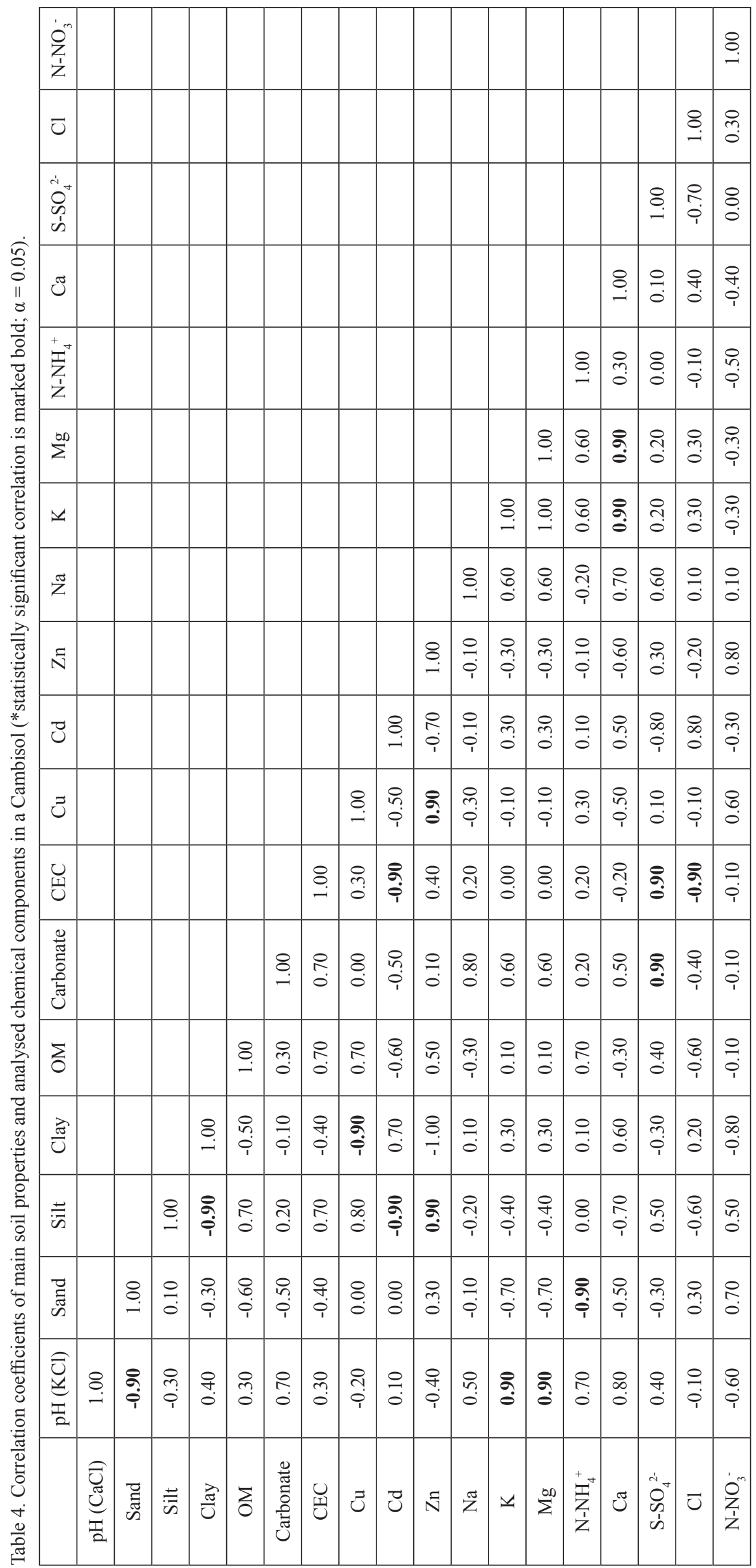




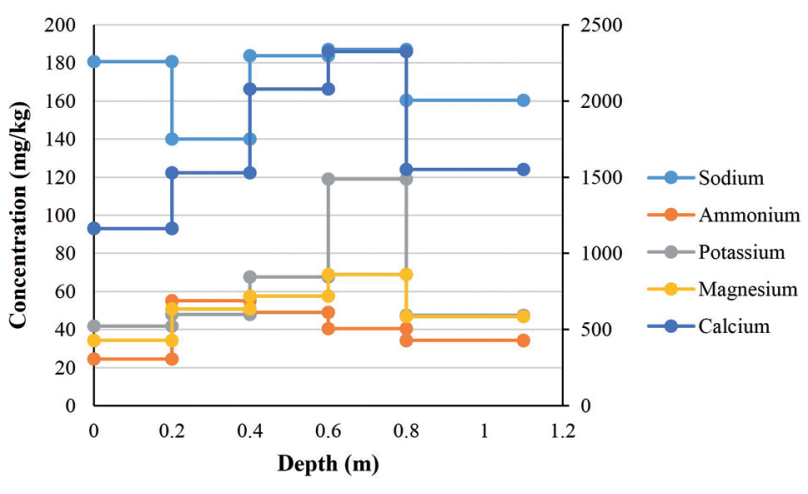

Fig. 5. Distribution of cations in soil profile.

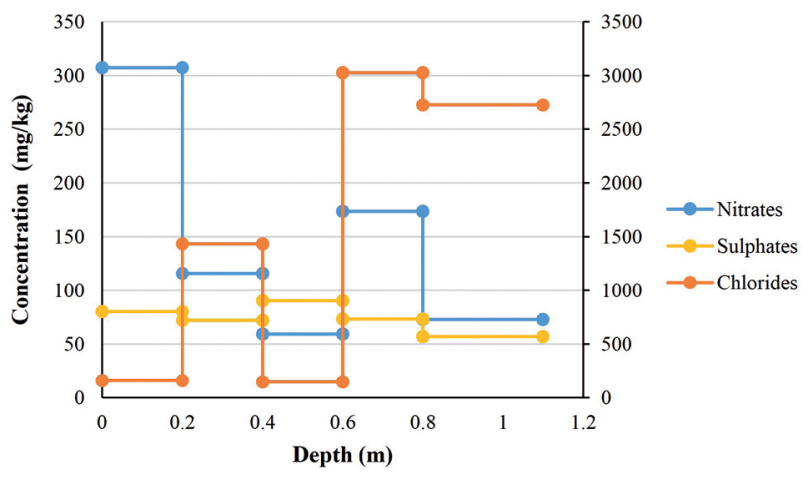

Fig. 6. Distribution of anions in soil profile.

are consistent with nitrate concentrations, which were measured in the groundwater of the Zagreb aquifer [38, 39] and are generally lower than those observed in the investigated soil profile.

According to Table 3, the dominant mineral phase in soil fraction below $2 \mu \mathrm{m}$ is illitic material. The second clay mineral in analysed soil is chlorite. Illite and chlorite have CEC from 15 to $40 \mathrm{meq} / 100 \mathrm{~g}$ [40], which corresponds with mineral determination. Soil horizons were rich in potassium as the result of high contents of clay mineral (illite). Prus et al. [41] found enriched potassium in Cambisol from illite mineral. Magnesium concentration is also enriched in soil horizons and it can be associated with clay minerals (chlorite/vermiculite).

Results of correlation matrix between physical and chemical soil properties and potentially toxic metal and ions contents in Cambisol are shown in Table 4. Soil $\mathrm{pH}$ and calcium concentration is in strong positive correlation. Bažon et al. [42] also reported positive strong correlations between these two parameters. Concentrations of $\mathrm{Zn}$ and $\mathrm{Cu}$ have significant correlations with silty fractions in analysed soil. Shelukindo et al. [43] reported similar positive correlations between these elements and siltous materials. A strong positive correlation between zinc and silt components has been observed, which suggests that $\mathrm{Zn}$ is strongly bound in silt component of analysed soil (Table 4). Cadmium concentrations are in negative strong correlation with $\mathrm{CEC}$ values.
Correlations between the concentrations of the studied potentially toxic metals and some soil properties, such as soil texture and CEC, may point out the prevalent mode of metals retention in soil. For instance, copper is in good correlation with organic matter in our study. Romić et al. [44] found significant positive correlation between $\mathrm{Cu}$ and the content of organic matter in their investigation of similar soils, which is consistent with our research. Copper forms stronger organic complexes and therefore soils rich in organic matter can retain more copper. Correlation results between ions are diverse. However, strong positive correlation of nitrates with sand and strong negative correlation of nitrates with clay have been observed. The higher sand content in the upper part of soil indicate the existence of an oxidative environment profile, which is in line with negative correlation with ammonium. Uzoho et al. [45] reported different correlations between nitrates and clay content in soil. Correlation results suggest that some nitrate concentration is bound to clay particles of studied soil, which is consistent with research of Mohsenipour et al. [46]. In this case, it is possible that some part of nitrate can be adsorbed to clay particles, which results in lower nitrate concentrations in the deeper part of the soil profile, but also in the Zagreb aquifer [38, 39]. In addition, a strong positive correlation between nitrates, copper and zinc has been observed, which may refer to the same origin of those elements, i.e., agricultural activity.

\section{Conclusions}

The soil of the study area is silty clay loam with generally decreasing sand and silt content and increasing clay content with depth. Organic matter showed similar distribution characteristics with CEC values, which confirms the existence of a higher percentage of leaves and microorganisms in upper parts of soil. The sequential chemical analysis presented diverse distribution in sequenced fractions of investigated soil. All analysed potentially toxic metals showed highest concentrations in RES fraction, which indicates the possible influence of agricultural activities such as usage of fertilizers, manure, fungicides, sludge as soil fertilizer or point sources of contamination, namely uncontrolled, active or untended waste dumps and aerodeposition. Most of the highest cation concentrations were determined in $2 \mathrm{C}$ horizon, while the lowest concentrations were observed in A horizon. The highest concentrations of anions were determined in $\mathrm{A}, \mathrm{C}$ and $2 \mathrm{C}$ horizons. Generally, it can be seen that most of ion concentrations are increasing until $0.8 \mathrm{~m}$ depth, while afterward they decrease. This indicates that agricultural activity probably has the highest influence on the first four soil horizons. Statistical analysis showed strong correlations between the concentrations of the studied potentially toxic metals and some soil properties, which may point out the prevalent mode of metals retention 
in soil. In addition, correlation results between nitrates and some potentially toxic metals such as $\mathrm{Cu}$ and $\mathrm{Zn}$ indicate that these elements come from the same source of contamination, in this case probably agricultural activity. Due to results of this research, it can be concluded that anthropogenic influence is evident. Even though results suggest that agriculture has an influence on soil quality, other possible sources of contamination should not be neglected. Implementation of protection measures, for example education of farmers and control and monitoring of application of fertilizer and manure, should be done. Also, detailed sampling of percolated water through soil profile in time and determination of basic water ions, as well as determination of concentrations of potentially toxic metals and their sorption parameters, should be of primary interest in future research.

\section{Acknowledgements}

I want to change it to: Publication process is supported by the Development Fund of the Faculty of Mining, Geology and Petroleum Engineering, University of Zagreb.

\section{Conflict of Interest}

The authors declare no conflict of interest.

\section{References}

1. BALDERACCHI M., BENOIT P., CAMBIER P., EKLO O.M., GARGINI A., GEMITZI A., GUREL M., KLÖVE B., NAKIĆ Z., PREDA E., RUŽIČIĆ S., WACHNIEW P., TREVISAN M. Groundwater pollution and quality monitoring approaches at European-level. Critical Reviews in Environment Science and Technology, 43, 323, 2011.

2. BONTEN L.T.C., RÖMKENS P.F.A.M., BRUS D.J. Contribution of heavy metal leaching from agricultural soils to surface water loads. Environment Forensics, 9, $252,2008$.

3. SCHIPPER P.N.M., BONTEN L.T.C., PLETTE A.C.C., MOOLENAAR S.W. Measures to diminish leaching of heavy metals to surface waters from agricultural soils. Desalination, 226, 89, 2008.

4. MEDUNIĆ G., CINDRIĆ JURANOVIĆ I., LOVRENČIĆ MIKELIĆ I., TOMAŠIĆ N., BALEN D., OREŠČANIN V., KAMPIĆ Š́., IVKOVIĆ I. Copper and zinc fractionation in apple orchard soil in the village of Bukevje (Croatia) using the revised four-step BCR extraction procedure. Archives of Industrial Hygiene and Toxicology, 64, 531, 2013.

5. BUBALO M., ROMIĆ D., ZOVKO M., KUSPILIĆ N. Agricultural Impact on Groundwater Vulnerability to Nitrate in Northern Croatia. Agriculturae Conspectus Scientificus, 79 (1), 23, 2014.

6. ZHANG Q.C., WANG G.H., FENG Y.K., QIAN P., SCHOENAU J.J. Effect of potassium fertilization on soil potassium pools and rice response in an intensive cropping system in China. Journal of Plant Nutrition Soil Science, 174, 73, 2011.

7. NAKIĆ Z., RUŽIČIĆ S., POSAVEC K., MILEUSNIĆ M., PARLOV J., BAČANI A., DURN G. Conceptual model for groundwater status and risk assessment - case study of the Zagreb aquifer system. Geologia Croatica, 66 (1), 55, 2013.

8. BASCH O. Basic geological map of SFRY 1:100 000, Ivanić Grad sheet - Geological Survey, Zagreb. Federal Geological Survey, Beograd. 1981 [In Croatian].

9. VELIĆ J., DURN G. Alternating Lacustrine-Marsh Sedimentation and Subaerial Exposure Phases during Quaternary: Prečko, Zagreb, Croatia. Geologia Croatica, 46 (1), 71, 1993.

10. POSAVEC K., VUKOJEVIĆ P., RATKAJ M., BEDENIKOVIĆ T. Cross-correlation Modelling of Surface Water - Groundwater Interaction Using the Excel Spreadsheet Application. The Mining-GeologicalPetroleum Engineering Bulletin, 32 (1), 25, 2017.

11. MARKOVIĆ T., BRKIĆ Ž., LARVA O. Using hydrochemical data and modelling to enhance the knowledge of groundwater flow and quality in an alluvial aquifer of Zagreb, Croatia. Science of the Total Environment, 458-460, 508, 2013.

12. RUŽIČIĆ S., MILEUSNIĆ M., POSAVEC K. Building Conceptual and Mathematical Model for Water Flow and Solute Transport in the Unsaturated zone at Kosnica Site. The Mining-Geological-Petroleum Engineering Bulletin, 25, 21, 2012.

13. HUSNJAK S. Systematic soils of Croatia. University of Zagreb, Zagreb. 2014 [In Croatian].

14. RUŽIČIĆ, S., KOVAČ, Z., NAKIĆ, Z., KIRETA, D. Fluvisol permeability estimation using soil water content variability. Geofizika, 34, 141, 2017.

15. MOORE D.M., REYNOLDS R.C. X-ray diffraction and the identification and analysis of clay minerals. Oxford University Press. Oxford, UK. 1989.

16. ISO 10693. Soil quality- Determination of carbonate content - Volumetric method. International Organisation for Standardisation, Switzerland, 1995.

17. MEHRA O.P., JACKSON M.L. Iron oxide removal from soils and clays by a dithionite-citrate system buffered with sodium bicarbonate. Clays and Clay Minerals. 7, 317, 1960.

18. ISO 13536. Soil quality-Determination of the potential cation exchange capacity and exchangeable cations using barium chloride solution buffered at $\mathrm{pH}=8$, 1 . International Organisation for Standardisation, Switzerland, 1995.

19. RAURET G., LÓPEZ-SÁNCHEZ J.F., BACON J., GÓMEZ A., MUNTAU H., QUEVAUVILLER P.H. Certification of the Contents (Mass Fractions) of $\mathrm{Cd}, \mathrm{Cr}, \mathrm{Cu}, \mathrm{Ni}, \mathrm{Pb}$ and $\mathrm{Zn}$ in an Organic-Rich Soil Following Harmonised EDTA and Acetic Acid Extraction Procedures, BCR-700. Report EUR 19774 EN, European Commission, Brussel, 2001.

20. DELL STATISTICA HELP, 2017 Available online: http://documentation.statsoft.com/STATISTICAHelp. aspx?path=common/About STATISTICA EletronicManualIndex/ (accessed on 1 of February 2015).

21. RUŽIČIĆ S., JAŠARAGIĆ-RAKO T. Multielement sorption of cadmium, zinc, copper and lead onto a Fluvisol profile at the Stara Loza site, Croatia. International Journal of Environment and Pollution, 62 (1), 63, 2017.

22. RUŽIČIĆ S., KOVAČ Z., TUMARA D. Physical and chemical properties in relation to soil permeability in the area of the Velika Gorica well field. The MiningGeological-Petroleum Engineering Bulletin, 33 (2), 73, 2018. 
23. LEŚNIEWSKA B., ŚWIERAD E., ŁUKOWSKI, A., WIATER J., GODLEWSKA-ŻYŁKIEWICZ B. Ultrasound assisted extraction for determination of mobile fractions of copper in soil. Roczniki Panstwowego Zakladu Higieny, 65 (1), 67, 2014.

24. NOGUEIROL R.C., ALLEONI L.R.F. Sequential extraction and speciation of $\mathrm{Ba}, \mathrm{Cu}, \mathrm{Ni}, \mathrm{Pb}$ and $\mathrm{Zn}$ in soil contaminated with automotive industry waste. Chemical Speciation \& Bioavailability, 25 (1), 34, 2013.

25. RUŽIČIĆ S., KOVAČ Z., TUMARA D. The impact of agriculture on the Cambisol soil developed in the area of the Velika Gorica well field. Congress Proceedings $2^{\text {nd }}$ International and $14^{\text {th }}$ National Congress of Soil Science Society of Serbia 28, 2018.

26. PAKUŁA K., KALEMBASA D. Copper Fractionation from Cambisols and Luvisols Using the BCR Procedure. Polish Journal of Environmental Studies, 22 (3), 809, 2013.

27. DELUISA A., GIANDON P., AICHNER M., BORTOLAMI P., BRUNA L., LUPETTI A., NARDELLI F., STRINGARI G. Copper pollution in Italian vineyard soils. Communications in Soil Science and Plant Analysis, 27 (5-8), 1537, 1996.

28. ROMIĆ M., ROMIĆ D. Heavy metals distribution in agricultural topsoils in urban area. Environmental Geology 43, 795, 2003.

29. DABIRI R., BAKHSHI MAZDEH M., MOLLAI H. Heavy metal pollution and identification of their sources in soil over Sangan iron-mining region, NE Iran. Journal of Mining \& Environment, 8 (2), 277, 2017.

30. BAKIRCIOGLU D., BAKIRCIOGLU KURTULUS Y., IBAR H. Investigation of trace elements in agricultural soils by BCR sequential extraction method and its transfer to wheat plants. Environment Monitoring and Assessment, 175, 303, 2011.

31. LIU B., AI S., GUO R., REN L., ZHANG W., ZHANG Y. Chemical Fractions and Mobility of $\mathrm{Cd}, \mathrm{Cu}, \mathrm{Pb}$ and $\mathrm{Zn}$ in Soil Profile of a Sewage Irrigation Area, Northwest China. Journal of Residuals Science \& Technology, 13 (1), 13, 2016.

32. HERNANDEZ-SORIANO M.C., JIMENEZ-LOPEZ J.C. Effects of soil water content and organic matter addition on the speciation and bioavailability of heavy metals. Science of the Total Environment, 423, 55, 2012.

33. AHMADIPOUR F., BAHRAMIFAR N., GHASEMPOURI S.M. Fractionation and mobility of cadmium and lead in soils of Amol area in Iran, using the modified BCR sequential extraction method. Chemical Speciation \& Bioavailability, 26 (1), 31, 2014.

34. ZHANG C., LI Z.Y., YANG W., PAN L., GU M., LEE D. Assessment of metals pollution on agricultural soil surrounding a lead-zinc mining area in the Karst region of
Guangxi, China. Bulletin of Environmental Contamination and Toxicology, 90, 736, 2013.

35. MOCANU VI., VOICU V., DUMITRU S., IGNAT P., MOCANU VA. The influence of mixed grass/legume pastures in crop rotation on soil quality - a study case on a Cambisol from southern Transylvania (Romania). AgroLife Science Journal, 5 (1), 138, 2016.

36. SEDLÁŘ O., BALÍK J., ČERNÝ J., PEKLOVÁ L., KUBEŠOVÁ K. Influence of nitrogen injection application on zinc and iron uptake by winter wheat and spring barley. Journal of Central European Agriculture, 15 (1), 39, 2014.

37. BAKŠIĆ D., PERNAR N., VUKELIĆ J., BARIČEVIĆ D. Properties of cambisol in beech-fir forests of Velebit and Gorski Kotar. Periodicum Biologorum, 110 (2), 119, 2008.

38. KOVAČ Z., NAKIĆ Z., PAVLIĆ K. Influence of groundwater quality indicators on nitrate concentrations in the Zagreb aquifer system. Geologia Croatica, 70 (2), 93, 2017.

39. KOVAČ Z., CVETKOVIĆ M., PARLOV J. Gaussian simulation of nitrate concentration distribution in the Zagreb aquifer. Journal of Maps, 13 (2), 727, 2017.

40. REGANOLD J.P., HARSH J.B. Expressing cation exchange capacity in milliequivalents per 100 grams and in SI units. Journal of Agriculture Education, 14 (2), 84, 1985.

41. PRUS T., ZUPANČIČ N., GRČMAN H. Soil of the lower valley of the Dragonja river (Slovenia). Acta Agriculturae Slovenica, 105 (1), 61, 2015.

42. BAŽON I., BAKIĆ H., ROMIĆ M. Soil Geochemistry as a Component of Terroir of the Wine-growing Station Jazbina, Zagreb. Agriculturae Conspectus Scientificus, 78 (2), 95, 2013

43. SHELUKINDO H.B., SEMU E., MSANYA B.M., SINGH B.R., MUNISHI P.K.T. Predictor variables for soil organic carbon contents in the Miombo woodlands ecosystem of Kitonga forest reserve, Tanzania. International Journal of Agricultural Science, 4 (7), 222, 2014

44. ROMIĆ M., ROMIĆ D., DOLANJSKI D., STRIČEVIĆ I. Heavy Metals Accumulation in Topsoils from the Winegrowing Regions. Agriculturae Conspectus Scientificus, 69 (1), 1, 2004.

45. UZOHO B.U., EMENYONU-CHRIS C., NWUFOR M.I., NZE E.O., EFFIONG J.A.L., NJOKU G.U. Nitrogen concentration in grain size fractions of soils of contrasting land units in the humid rainforest, southeastern Nigeria. Intern. International Journal of Environmental and Pollution Research, 4 (3), 12, 2016.

46. MOHSENIPOUR M., SHAMSUDDIN S., KUMARS E. Nitrate Adsorption on Clay Kaolin: Batch Tests. E-Journal of Chemistry, 2015, 1, 2015. 